UDC 544.723.21

\title{
ON THE CORRELATION BETWEEN CHARACTERISTICS OF CATALYST PARTICLES AND CHANGES IN POROUS STRUCTURE OF ACTIVATED CARBON IN IRON-CATALYZED CARBON HYDROGENATION REACTION
}

\author{
O.N. Stavinskaya \\ Chuiko Institute of Surface Chemistry of National Academy of Sciences of Ukraine \\ 17 General Naumov Str., Kyiv, 03164, Ukraine
}

The sizes and composition of iron-containing particles formed in pores of activated carbon during heat treatment in flowing hydrogen have been studied by Mossbauer spectroscopy. The changes in porous structure of activated carbon due to iron-catalyzed carbon hydrogenation were investigated by means of adsorption method. With the same percentages of burn-off, the sizes of pores formed in the adsorbent during activation have been found to increase for the sample with higher iron loading and larger catalyst particles.

\section{INTRODUCTION}

Presence of well-developed mesopores in porous texture of carbon adsorbents may be desirable in various fields of carbon applications and activation of carbon materials in catalytic processes appears to be a simple way to develop carbons mesoporosity [1]. Gasification of carbon by using a catalyst also seems to give an opportunity to effect the changes in porous texture of carbon adsorbents during activation. In our previous studies $[2,3]$ on activated carbons containing 10-20 wt.\% of iron and hydrogenated at temperature in excess of $500{ }^{\circ} \mathrm{C}$ we have found that, under the same treatment conditions, sizes of mesopores generated depended on iron loading and could be affected by low temperature samples pretreatment leading to changes in particles size prior to carbon gasification initiation. The present communication contains some additional data supporting the idea of the correlation between characteristics of catalyst particles and changes in porous structure of activated carbons in the course of iron-catalyzed carbon hydrogenation.

\section{EXPERIMENTAL}

Spherically granulated synthetic activated carbon (AC) from a copolymer of styrene and divinylbenzene [4], with a particle size of 0.4$0.6 \mathrm{~mm}$, was used as a starting material for investigation. S1 and S2 samples with iron loading of $C_{\mathrm{Fe}}=5$ and $2 \mathrm{wt}$. \% were prepared by

\footnotetext{
* corresponding author okstavinskaya@yahoo.com
}

impregnation of starting carbon with aqueous solutions of iron(III) nitrate of different concentration. After drying in air at room temperature both the samples were heated for $90 \mathrm{~min}$ in flowing hydrogen at the pressure of $1 \mathrm{~atm}$ and at the temperature of $350^{\circ} \mathrm{C}$, which is less than carbon ignition temperature, and then hydrogenated at 550 and $700{ }^{\circ} \mathrm{C}$.

The study of iron-containing particles was carried out by means of Mossbauer spectroscopy. The Mossbauer spectra were obtained at $80 \mathrm{~K}$ with a conventional constantacceleration spectrometer and ${ }^{57} \mathrm{Co}$ in chromium matrix used as a source. Isomer shifts are presented relative to a metallic iron. The spectra were fitted using the approximation of Lorentzian line shape.

The parameters of porous structure for starting and iron-containing carbons were found from the benzene adsorption isotherms, the total pore volume $V_{\Sigma}$ of the samples was determined by means of their impregnation with acetone. Volume of micropores $V_{\mathrm{mi}}$ and mesopores $V_{\mathrm{me}}$ and surface area of mesopores $S_{\text {me }}$ were calculated according to the theory of volume filling of micropores for the case of micromesoporous adsorbents [5]; the Broekhoffde Boer-Dubinin method [6] was used to determine the pore size distribution over radius. Referring the pores to micro- and mesopores was made in accordance with Dubinin's classification of micro- and mesopores (pores with radii $r<1.5-1.6 \mathrm{~nm}$ and $1.5-1.6<r<100-200 \mathrm{~nm}$, 
respectively) [5]. The parameters of porous structure for starting and iron-containing carbons are given per $1 \mathrm{~cm}^{3}$ of the samples.

\section{RESULTS AND DISCUSSION}

Figure 1 shows the Mossbauer spectra of S1 sample treated in hydrogen at $350-700^{\circ} \mathrm{C}$; spectra of $\mathrm{S} 2$ samples were similar to those of $\mathrm{S} 1$ ones and differed from them only by contribution of various signals to the overall spectra. Time of heat treatment at each temperature is $90 \mathrm{~min}$. The following components can be distinguished in the spectra: a doublet with an isomer shift of $\delta=0.36 \pm 0.05 \mathrm{~mm} / \mathrm{s}$ and quadrupole splitting of $\Delta E_{\mathrm{Q}}=0.83-0.93 \mathrm{~mm} / \mathrm{s}$ (spectra 1-3); an intensive singlet with isomer shift of $\delta=-0.1 \pm 0.05 \mathrm{~mm} / \mathrm{s}$ and linewidth of $\Gamma=0.29 \pm 0.05 \mathrm{~mm} / \mathrm{s}$ (spectrum 3 of the sample treated at $700^{\circ} \mathrm{C}$ ); a sharp sextet I with hyperfine parameter $H_{\text {eff }}=340 \mathrm{kOe}$ (spectra 2, 3) and a broad sextet II with $H_{\text {eff }}$ up to $490 \mathrm{kOe}$ (spectra $1-3$ ). In accordance to numerous Mossbauer studies on ironcontaining particles of various sizes and structure, the subspectra mentioned above can be assigned, respectively, to small iron oxide particles with diameter $d<3-5 \mathrm{~nm}$ [7-9], to non-magnetic austenite structure, to metallic iron with particle size of $d \geq 10-12 \mathrm{~nm}$ and to superparamagnetic at $80 \mathrm{~K}$ iron oxides having the diameter $3-5 \mathrm{~nm}<d<10-13 \mathrm{~nm}$ [10-14].

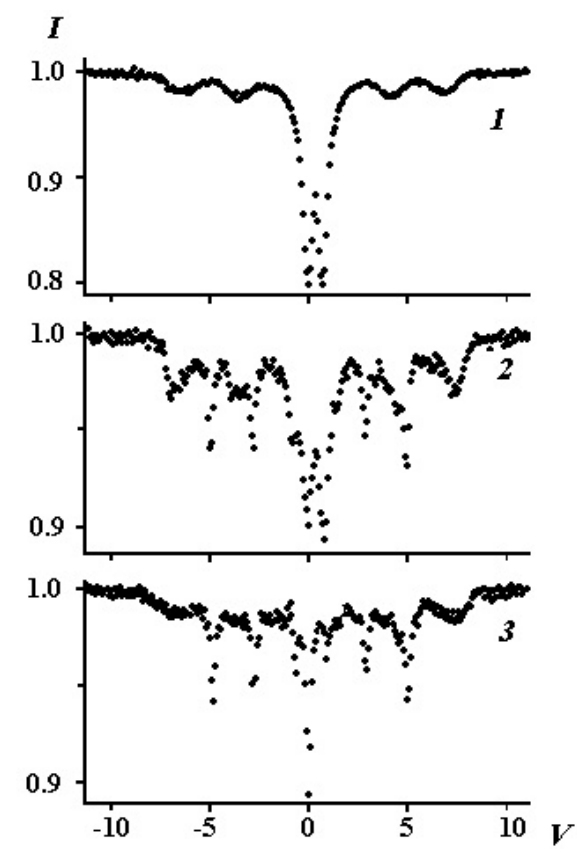

Fig. 1. Mossbauer spectra $(80 \mathrm{~K})$ of $\mathrm{S} 1$ sample after heat treatment in hydrogen at 350 (1), 550 (2) and $700{ }^{\circ} \mathrm{C}(3) . V$ - velocity, $\mathrm{mm} / \mathrm{s} ; I$ - relative transmission
Table 1 gives the fitting parameters for the spectra 1-3 with the assymetric lines of sextet II in the spectra $2-3$ being simulated as superposition of two sextets (sextet II.1 and sextet II.2) having Lorentzian line shape. Table 2 gives the relative areas of the subspectra for all the spectra measured with the data being presented in terms of iron distribution between the particles of different sizes and composition. Percentages of iron atoms in the smallest oxide particles $(d<3-5 \mathrm{~nm})$ in austenite structure and in metallic iron were determined, respectively, as the partial area of doublet, singlet and sextet with $H_{\text {eff }}=340 \mathrm{kOe}$. The difference between the area of the overall spectra and the partial areas of doublet, singlet, and sextet I was attributed to oxide particles with $3-5 \mathrm{~nm}<d<$ $10-13 \mathrm{~nm}$.

It can be seen from Table 2 that increase in iron loading leads to increase in particles sizes and in amount of metallic iron, which is a catalyst for carbon hydrogenation reaction [15]. It should be noted, however, that high content of iron oxides in $\mathrm{S} 1$ and $\mathrm{S} 2$ samples after reduction at $550-700{ }^{\circ} \mathrm{C}$ appears to be a result of an oxidation of small iron particles after exposing to air and that in the reducing atmosphere the majority of these particles has to be in a form of metallic iron too. The supports for this conclusion are the known property of iron particles with $d<10 \mathrm{~nm}$ to be converted into iron oxides by exposing to air, small sizes of oxide particles formed in $\mathrm{S} 1$ and S2 samples and our previous data [16-18] on the kinetics of iron oxides reduction in the same activated carbon.

Table 3 gives the total pore volume, those of micro- and mesopores and the surface area of mesopores for starting and hydrogenated carbons, Fig. 2 shows mesopore size distribution curves. As can be seen from Table 3, a rapid activation of iron-containing samples takes place during hydrogen treatment at $550-700{ }^{\circ} \mathrm{C}$. Increase in volume of sorption pores mainly occurs due to mesopores development: the $V_{\mathrm{me}}, S_{\mathrm{me}}$ values for activated samples are enhanced by a factor of up to 2 compared to the starting carbon. Formation of mesopores with radii $r<10-11 \mathrm{~nm}$ prevails at the initial stages of the samples treatment (Fig. 2) while a growth of larger mesopores a gradual disappearance of micropores and a partial conversion of mesopores into macropores occurs with the proceeding of activation (Fig. 2, Table 3 ). 
Table 1. Mossbauer parameters of the spectra $(\mathrm{T}=80 \mathrm{~K})$ shown in Figure 1

\begin{tabular}{ccccccc}
\hline Spectrum & Subspectra & $\begin{array}{c}\boldsymbol{\delta} \\
( \pm \mathbf{0 . 0 5} \mathbf{~ m m} / \mathbf{s})\end{array}$ & $\begin{array}{c}\boldsymbol{\Delta} \boldsymbol{E}_{\mathbf{Q}} \\
( \pm \mathbf{0 . 0 5} \mathbf{~ m m} / \mathbf{s})\end{array}$ & $\begin{array}{c}\boldsymbol{H}_{\text {eff }} \\
( \pm \mathbf{3 ~ k O e})\end{array}$ & $\begin{array}{c}\boldsymbol{\Gamma} \\
( \pm \mathbf{0 . 0 5} \mathbf{~ m m} / \mathbf{s})\end{array}$ & $\begin{array}{c}\text { Relative area } \\
( \pm \mathbf{3} \%)\end{array}$ \\
\hline 1 & doublet & 0.36 & 0.83 & - & 0.63 & 59 \\
& sextet II & 0.36 & 0.04 & 455 & 1.89 & 41 \\
\hline 2 & doublet & 0.36 & 0.93 & - & 0.78 & 29 \\
& sextet I & 0.00 & 0.01 & 340 & 0.38 & 20 \\
& sextet II.1 & 0.33 & 0.06 & 490 & 0.68 & 21 \\
& sextet II.2 & 0.33 & 0.14 & 438 & 1.58 & 30 \\
\hline 3 & doublet & 0.36 & 0.90 & - & 0.76 & 3 \\
& singlet & -0.10 & - & - & 0.29 & 8 \\
& sextet I & 0.00 & 0.00 & 338 & 0.23 & 18 \\
& sextet II.1 & 0.47 & 0.29 & 483 & 1.46 & 28 \\
& sextet II.2 & 0.10 & 0.45 & 309 & 2.44 & 43 \\
\hline
\end{tabular}

Table 2. Distribution of iron atoms in iron-containing particles of various size and composition for S1, S2 samples treated in hydrogen at $350-700{ }^{\circ} \mathrm{C}$

\begin{tabular}{cccccc}
\hline \multirow{2}{*}{ Sample } & $\begin{array}{c}\text { Final heat } \\
\text { treatment, } \\
\mathbf{9 0} \mathbf{~ m i n}\end{array}$ & $\begin{array}{c}\text { iron oxides particles, } \\
\boldsymbol{d}<\mathbf{3}-\mathbf{5} \mathbf{~ n m}\end{array}$ & $\begin{array}{c}\text { Percentage of iron atoms in: } \\
\text { iron oxides particles, } \\
\mathbf{3}-\mathbf{5}<\boldsymbol{d}<\mathbf{1 0}-\mathbf{1 3} \mathbf{~ n m}\end{array}$ & $\begin{array}{c}\text { metallic iron, } \\
\boldsymbol{d} \geq \mathbf{1 0}-\mathbf{1 2} \mathbf{~ n m}\end{array}$ & austenite \\
\hline $\mathrm{S} 1$ & $350^{\circ} \mathrm{C}$ & 59 & 41 & - & - \\
& $550^{\circ} \mathrm{C}$ & 29 & 51 & 20 & - \\
& & 3 & 71 & 18 & 8 \\
$\mathrm{~S} 2$ & $700^{\circ} \mathrm{C}$ & 64 & 36 & - & - \\
& $350^{\circ} \mathrm{C}$ & 41 & 54 & 6 & 5 \\
\hline
\end{tabular}

Table 3. Some characteristics of porous texture for starting and activated carbons

\begin{tabular}{|c|c|c|c|c|c|c|}
\hline Sample & $\begin{array}{l}\text { Final heat } \\
\text { treatment }\end{array}$ & $\begin{array}{c}\text { Burn-off, } \\
\% \\
\end{array}$ & $\begin{array}{c}V_{\Sigma}, \\
\mathrm{cm}^{3} / \mathrm{cm}^{3} \\
\end{array}$ & $\begin{array}{c}V_{\text {mi }}, \\
\mathrm{cm}^{3} / \mathbf{c m}^{3} \\
\end{array}$ & $\begin{array}{c}V_{\text {me }}, \\
\mathrm{cm}^{3} / \mathrm{cm}^{3} \\
\end{array}$ & $\begin{array}{c}S_{\text {me }}, \\
\mathbf{m}^{2} / \mathbf{c m}^{3} \\
\end{array}$ \\
\hline $\mathrm{AC}$ & - & 0 & 0.37 & 0.10 & 0.09 & 35 \\
\hline \multirow[t]{3}{*}{$\mathrm{S} 1$} & $550{ }^{\circ} \mathrm{C}, 40 \mathrm{~min}$ & 31 & 0.41 & 0.08 & 0.14 & 53 \\
\hline & $550^{\circ} \mathrm{C}, 90 \mathrm{~min}$ & 55 & 0.47 & 0.05 & 0.15 & 47 \\
\hline & $700^{\circ} \mathrm{C}, 90 \mathrm{~min}$ & 72 & 0.50 & 0.02 & 0.13 & 38 \\
\hline \multirow[t]{3}{*}{$\mathrm{S} 2$} & $550^{\circ} \mathrm{C}, 90 \mathrm{~min}$ & 32 & 0.41 & 0.10 & 0.13 & 55 \\
\hline & $550{ }^{\circ} \mathrm{C}, 90 \mathrm{~min}$ & 56 & 0.48 & 0.08 & 0.15 & 65 \\
\hline & $700^{\circ} \mathrm{C}, 90 \mathrm{~min}$ & 72 & 0.50 & 0.02 & 0.18 & 70 \\
\hline
\end{tabular}

The data on activation of the S1, S2 samples treated under the same conditions do not reveal a simple relationship between catalyst loading and the percentage of carbon burn-off (Table 3 ) that appears to be due to the number and complexity of the factors which influence the rate of catalyzed reaction of carbon gasification. At the same time, there is a qualitative correlation between characteristics of catalyst particles and variation in the porous texture of activated samples, namely: in the S2 sample having lower iron content and smaller particles, narrower pores are formed and vice versa. Really, S1 and S2 samples hydrogenated under the same conditions are characterized by practically the same percentages of burn-off (Table 3) and the total pore volume, while at all stages of activation, S1 samples differ from $\mathrm{S} 2$ ones by smaller volume of pores with $r<8-11 \mathrm{~nm}$ and by greater amount of the broader pores (Fig. 3). With the highest degrees of burn-off (72\%), S2 sample retains well enhanced amount of mesopores compared to the starting carbon, whereas in the case of S1 samples the majority of these pores appears to be converted into macropores (Table 3, Fig. $2 c$ ).

The distinctions in porous texture of S1 and $\mathrm{S} 2$ carbon activated under the same conditions to the similar percentages of burn-off can be explained as follows. According to [15], gasification of carbon in catalytic process occurs in the immediate vicinity of catalyst particles, giving rise to the development of pores where the particles are located. Gasification of carbon 
with metallic catalyst can be also accompanied by channeling or pitting the carbon substrate $[15,19]$, with the sizes of the voids being dependent on the sizes of the catalyst particles.
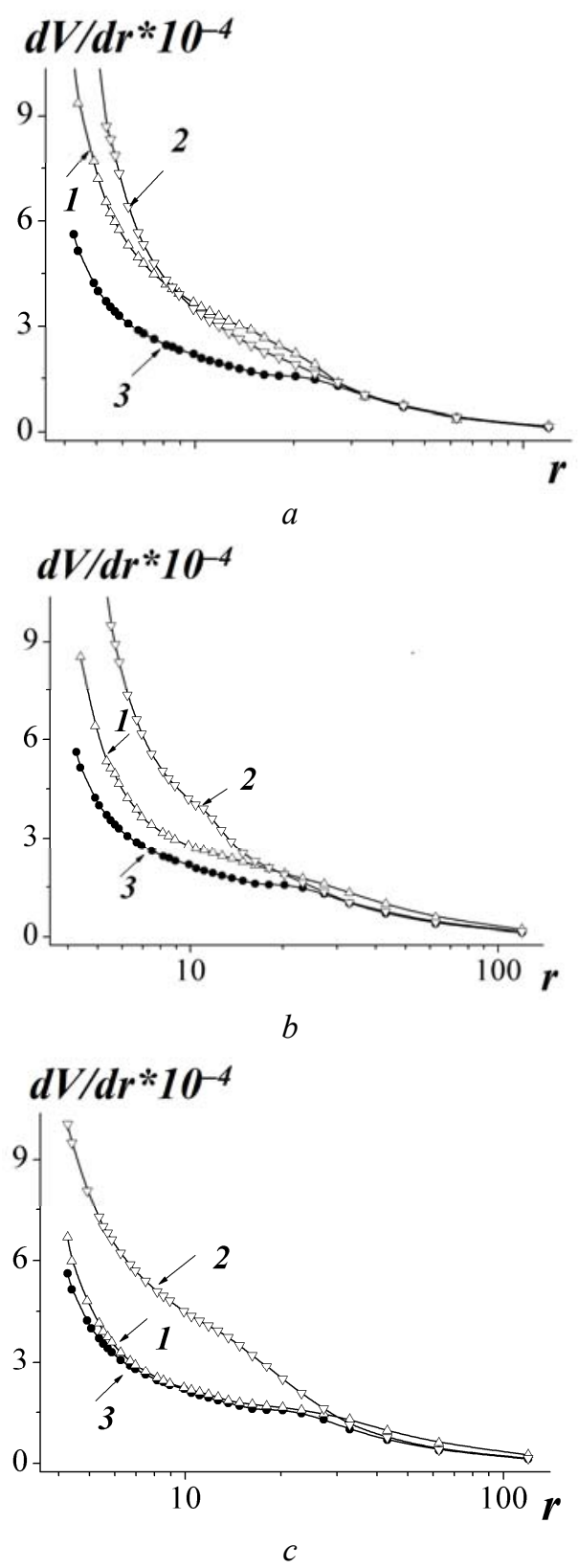

Fig. 2. Mesopore size distribution curves for $\mathrm{S} 1$ (1) and S2 (2) samples activated to 31-32 (a), 55-56 (b) and $72(c)$ percentages of burn-off. Curve 3 gives mesopore size distribution for starting $\mathrm{AC}[\boldsymbol{d} \boldsymbol{V} / \boldsymbol{d} \boldsymbol{r}]=\mathrm{cm}^{2} / \mathrm{cm}^{3},[\boldsymbol{r}]=\mathrm{nm}$

Thus, both dispersity of catalyst particles and their distribution in carbon pores must influence the changes in porous texture of activated carbon during hydrogenation. Increase in iron loading leads to an increase in the size and the number of iron particles that, in turn, may result in increase in the diameter of the voids and in probability for them to coalescence. Another important moment is that enhancement of iron content leads to an increase in amount of catalyst in broad pores. As the rate of reactions in porous solids may depend on sizes of pores and decreases with the pore diameter, the catalyst particles located in wider pores have to play a more important role in carbon gasification. Therefore, a general increase in iron content must result in development of wide pores rather than in growth of narrow ones.

\section{REFERENCES}

1. Oya A., Yoshida S., Alcaniz-Monge J., LinaresSolano $A$. Formation of mesopores in fenolic resin-derived carbon fiber by catalytic activation using cobalt // Carbon. - 1995. - V. 33, N 8. P. 1085-1090.

2. Stavinskaya O.N., Shklovskaya N.I. Variation in the porous strucrure of iron-containing carbons during hydrogenation // Rus. J. Phys. Chem. 1997. - V. 71, N 9. - P. 1665-1671.

3. Stavinskaya O.N., Shklovskaya N.I. Some peculiarities of the process of activation of synthetic carbons in iron-catalyzed carbon hydrogenation reaction // Rus. J. Phys. Chem. 1999. - V. 72, N 5. - P. 751-755.

4. Burushkina T.N., Aleinikov V.G., Kislitsyn N.A., Myasnikov V.K. A study of the process of the porous structure formation for activated carbon from a copolymer of styrene and divinylbenzene // Adsorbtsiya i adsorbenty (Adsorption and Adsorbents). - 1979. - N 7. - P. 15-19 (in Russian).

5. Dubinin M.M. Fundamentals of the theory of adsorption in micropores of carbon adsorbents: characterization of their adsorption properties and microporous structure // Carbon. - 1989. V. 27, N 3. - P. 457-467.

6. Dubinin M.M., Kataeva L.I. Capillar phenomena and information on porous structure of adsorbents: distribution of mesopore volume and mesopore surface of carbon adsorbents from benzene and nitrogen capillar evaporation experiment // Izv. Akad. Nauk SSSR, Ser. Khim. - 1980. - N 3. - P. 498-502 (in Russian).

7. Niemantsverdriet J.W., van der Kraan A.M., Delgass W.N., Vannice M.A. Small particles effects in Mossbauer spectra of a carbonsupported iron catalyst // J. Phys. Chem. - 1985. - V. 89, N 1. - P. 67-72.

8. Giessen A.A. Magnetic properties of ultra-fine iron(III) oxide-hydrate particles prepared from iron(III) oxide-hydrate gels // J. Phys. Chem. Solids. - 1967. - V. 28, N 2. - P. 343-346.

9. Aharoni S.M., Litt M.H. Superpara-magnetism and exchange anisotropy in microparticles of $\mathrm{Fe}_{3} \mathrm{O}_{4}$ 
embedded in inert carbonaceous matrix // J. Appl. Phys.- 1971. - V. 42, N 1. - P. 352-357.

10. Roggwiller P., Kundig $W$. Mossbauer spectra of superparamagnetic $\mathrm{Fe}_{3} \mathrm{O}_{4} / /$ Solid State Commun. - 1973. - V. 12, N 9. - P. 901-903.

11. Maneda Y., Aramaki M., Takashima Y. et al. Mossbauer study of iron oxide layers formed on fine iron particles // Bull. Chem. Soc. Jpn. - 1987. - V. 60, N 11. - P. 3241-3246.

12. McNab T.K., Fox R.A., Bovie A.J.F. Some magnetic properties of magnetite $\left(\mathrm{Fe}_{3} \mathrm{O}_{4}\right)$ microcrystalls // J. Appl. Phys. - 1972. - V. 39, N 12. - P. 5703-5711.

13. Suzdalev I.P. On superparamagnetism of ultrafine antiferromagnetic particles // Fiz. Tverd. Tela. - 1970. - V. 12, N 4. - P. 988-990 (in Russian).

14. Haneda K., Morrish A.H. Vacancy ordering in $\gamma$ $\mathrm{Fe}_{2} \mathrm{O}_{3}$ small particles // Solid State Commun. 1977. - V. 22, N 12. - P. 779-782.
15. McKee D.W. The catalyzed gasification reactions of carbon // Chemistry and Physics of Carbon / Walker Jr. PL, Thrower PA., eds. NewYork: Marcell Dekker, 1981. - V. 16. - P. 1-121.

16. Stavinskaya O.N., Imshennik V.K., Oranskaya E.I. et al. Dispersity and composition of ironcontaining particles in adsorbents prepared from synthetic active carbons // Rus. J. Phys. Chem. 1998. - V. 72, N 7. - P. 1138-1143.

17. Stavinskaya O.N., Imshennik V.K. Structure of ironcontaining particles deposited on carbon as studied by Mossbauer spectroscopy // Rus. J. Phys. Chem. 2000. - V. 74, N 11. - P. 2107-2112.

18. Stavinskaya O.N., Imshennik V.K. The reduction of iron-containing particles deposited on carbon under the conditions of iron-catalyzed carbon hydrogenation. // Rus. J. Phys. Chem. - 2006. V. 80, N 12. - P. 1925-1928.

19. Chu X., Schmidt L.D. Gasification of graphite studied by scanning tunneling microscopy // Carbon. - 1991. - V. 29, N 8. - P. 1251-1255.

Received 19.10.2012, accepted 18.01.2013

\section{Взаємозв'язок між характеристиками частинок каталізатора та зміною пористої структури активного вугілля в каталізованій залізом реакції гідрогенізації вуглецю}

\section{О.М. Ставинська}

Інститут хімії поверхні ім. О.О. Чуйка Наиіональної академії наук України вул. Генерала Наумова, 17, Київ, 03164, Україна, okstavinskaya@yahoo.com

Методом мессбауерівської спектроскопії вивчено склад і розміри залізовмісних частинок, щяо формуються в порах активного вугілля при термообробиі в атмосфері водню. Адсорбиійним методом досліджено зміну пористої структури вугілля внаслідок каналізованої залізом реакиіі гідрогенізації вуглецюю. Знайдено, щзо при однакових значеннях обгару розміри пор, щзо формуються в адсорбенті при активуванні, збільшуються у зразка з більшим вмістом заліза $і$ з більшими розмірами частинок каталізатора.

\section{Взаимосвязь между характеристиками частиц катализатора и изменением пористой структуры активного угля в катализируемой железом реакции гидрогенизации углерода}

\section{О.Н. Ставинская}

Институт химии поверхности им. А.А. Чуйко Национальной академии наук Украины ул. Генерала Наумова, 17, Киев, 03164, Украина, okstavinskaya@yahoo.com

Методом мессбауэровской спектроскопии изучены состав и размеры железосодержащих частии, образуюшихся в порах активного угля в прочессе термообработки в атмосфере водорода. Адсорбиионным методом изучено изменение пористой структуры активного угля в результате катализируемой железом реакиии гидрогенизации углерода. Обнаружено, что при одинаковых значениях обгара размеры пор, образуюшихся в адсорбенте при активировании, увеличиваются для образиа с большим содержанием железа и с большими размерами частии катализатора. 